\title{
Immune competence of the mammary gland as affected by somatic cell and pathogenic bacteria in ewes with subclinical mastitis
}

\author{
M. Albenzio, ${ }^{1}$ A. Santillo, M. Caroprese, D. Ruggieri, M. Ciliberti, and A. Sevi \\ Department of Production and Innovation in Mediterranean Agriculture and Food Systems (PrIME), University of Foggia, \\ Via Napoli, 25, 71100 Foggia, Italy
}

\begin{abstract}
Immune competence of the ewe mammary gland was investigated by monitoring the leukocyte differential count, cytokine pattern, and endogenous proteolytic enzymes in milk samples with different somatic cell counts (SCC) and pathogenic bacteria. Furthermore, the leukocyte differential count and T-lymphocyte populations were evaluated in ewe blood. A total of 1,500 individual milk samples were randomly selected from the pool of the samples collected during sampling and grouped into 5 classes of 300 samples each, on the basis of SCC. Classes were $<300,000$ cells $/ \mathrm{mL}$, from 300,000 to 500,000 cells $/ \mathrm{mL}$, from 501,000 to $1,000,000$ cells $/ \mathrm{mL}$, from $1,001,000$ to $2,000,000$ cells $/ \mathrm{mL}$, and $>2,000,000$ cells/mL. Microbiological analyses of ewe milk were conducted to detect mastitis-related pathogens. Sheep whose udders were without clinical abnormalities, and whose milk was apparently normal but with at least $10^{3}$ $\mathrm{cfu} / \mathrm{mL}$ of the same pathogen were considered to have subclinical mastitis and therefore defined as infected. Polymorphonuclear neutrophilic leukocytes (PMNL) and macrophages increased with SCC, whereas lymphocytes decreased. Milk samples with SCC $>1,000,000$ cells/mL showed differences in leukocyte populations between uninfected and infected ewes, with higher percentages of PMNL and macrophages and lower percentages of lymphocytes in infected animals. Nonviable PMNL levels were the highest in ewe milk samples with SCC $<300,000$ cells $/ \mathrm{mL}$; starting from SCC $>500,000$ cells/mL, nonviable PMNL were higher in uninfected ewes than in infected ones. In infected animals giving milk with $\mathrm{SCC}>1,000,000$ cells $/ \mathrm{mL}$, a higher $\mathrm{CD}^{+} /$ $\mathrm{CD} 8^{+}$ratio was observed, suggesting that the presence of pathogens induced an activation of both $\mathrm{CD} 4^{+}$and $\mathrm{CD} 8^{+}$. The levels of tumor necrosis factor- $\alpha$ and IL-12 were higher in infected than uninfected ewes, irrespective of SCC. Plasmin activity increased along with
\end{abstract}

Received January 18, 2012.

Accepted March 1, 2012.

${ }^{1}$ Corresponding author: m.albenzio@unifg.it
SCC and was always higher in infected than uninfected animals; cathepsin D increased starting from 1,001,000 cells $/ \mathrm{mL}$ in milk samples from noninfected ewes and starting from 301,000 cells/mL in milk samples from infected animals. The associations between somatic cells, cytokines, endogenous proteolytic enzymes, and pathogenic bacteria can be used to better understand the pathogenesis of subclinical mastitis in ewes and the effect on the immune response of ewe mammary gland. Key words: somatic cell count, pathogen, leukocyte differential count, interleukin

\section{INTRODUCTION}

The mammary gland is under constant threat from a variety of contagious and environmental pathogens. Studies on ewes and goats have shown that the prevalence of contagious pathogens is reduced as a result of the effective application of control and prevention strategies (Contreras et al., 2007), whereas the proportion of environmental pathogens has become a major problem on many well-managed dairy farms that have successfully controlled contagious pathogens (Oliver and Pighetti, 2003).

Measurement of total bacterial count, or presence of specific types of bacteria, and SCC represent the elective standards to evaluate animal health status and milk quality. Together with SCC, determination of the differential cell count in milk is a useful approach to evaluate the proportion of leukocytes during inflammation and thus the immune status of the mammary gland. In ewe milk samples, flow cytometry was used to detect the percentage of PMNL, macrophages, and lymphocytes in bulk and individual milk with different SCC (Albenzio et al., 2009, 2011; Albenzio and Caroprese, 2011).

Intramammary infection induces an increase in endothelium permeability to the passage of components from blood to milk, such as neutrophils, cytokines, and endogenous enzymes. Phagocytic neutrophils are the key immune effectors in the battle between host and pathogens due to their rapid recruitment and ability to release several antibacterial components. The role 
of cytokines in mammary gland immune defense is ascribed to the recruitment of leukocytes to the tissue and the increase in phagocytic bactericidal activity. Endogenous proteolytic enzymes in milk, mainly represented by the plasmin system, cathepsin $\mathrm{D}$, and elastase, are associated with leukocytes and are involved in milk casein breakdown.

The immune response of the mammary gland differs along with the etiological agent. Thus, the knowledge of host and pathogen factors involved in the development and establishment of IMI as well as defense mechanisms within the udder represent a useful approach to diagnosis and control of mammary gland inflammation.

This research was undertaken to evaluate mammary gland health status by studying (1) the leukocyte differential count; (2) the cytokine pattern; and (3) endogenous proteolytic enzymes in ewe milk samples with different SCC and pathogenic bacteria. Furthermore, the leukocyte differential count and T-lymphocyte populations were evaluated in ewe blood.

\section{MATERIALS AND METHODS}

\section{Experimental Design and Milk Sampling}

The experiment was conducted in an intensively managed commercial dairy flock consisting of 700 Comisana ewes, located in southern Italy. The ewes were milked twice daily in a parlor using a pipeline milking machine; before milk collection, ewes were carefully examined by a veterinarian to confirm the absence of any sign of clinical mastitis such as fever, pain or gland swelling and a small quantity of milk was checked visually for signs of mastitis. Because of clinical mastitis, 24 ewes were excluded from the study. Staphylococcus aureus was the etiological agent for most of the clinical mastitis cases. Animal handling followed the recommendations of European Union directive 86/609/ EEC (EEC, 1986) concerning animal care. Milk SCC was detected using a Fossomatic Minor (Foss Electric, Hillerød, Denmark) according to the International Dairy Federation standard (IDF, 1995); classes were $<300,000$ cells/mL (SC300); from 300,000 to 500,000 cells/mL (SC500); from 501,000 to $1,000,000$ cells/ $\mathrm{mL}$ (SC1000); from 1,001,000 to $2,000,000$ cells $/ \mathrm{mL}$ (SC2000); and >2,000,000 cells/mL ( $\mathbf{S C}>\mathbf{2 0 0 0})$.

Four sampling cycles were performed over a 6-mo period; each sampling cycle was conducted over a 3 -wk period. At each sampling time, individual milk samples were analyzed for SCC over 3 consecutive days to verify the level of SCC over time in the same milk sample; on the fourth sampling day, the sample that showed the same SCC as the 3 previous days was included in the study and assigned to 1 of the 5 SCC classes. In total, 736 samples were rejected due to inconsistent SCC over the 3 consecutive days.

In total, 1,500 individual ewe milk samples, 300 samples for each SCC class, were randomly selected from the pool of samples collected during milk sampling and used for the study.

\section{Microbiological Analysis of Milk}

Presumptive Escherichia coli were detected after a 24-h incubation period on violet red bile agar with 4-methylumbelliferyl-(-D-glucuronide) at $44.5 \pm 0.5^{\circ} \mathrm{C}$. Staphylococci were detected after a 48-h incubation period on Baird Parker agar (Oxoid, Basingstoke, UK) supplemented with egg yolk tellurite emulsion at $37^{\circ} \mathrm{C}$ and subsequently identified at species level using the API-Staph System (bioMerieux, Marcy l'Etoile, France). Enterococci were determined on Slanetz-Bartley medium (Biolife, Milan, Italy) and pyogenic streptococci on modified Edwards esculin medium (Oxoid) at $37^{\circ} \mathrm{C}$ after $24-$ to 48 -h incubation. Streptococcal isolates were then speciated using the API 20 Strep System (bioMerieux). Pseudomonas spp. were determined using Pseudomonas selective agar (Oxoid); Pseudomonas aeruginosa was detected after a 3-d incubation on Pseudomonas agar $\mathrm{F}$ and Pseudomonas agar $\mathrm{P}$ (Oxoid) at 32 to $37^{\circ} \mathrm{C}$. Samples were considered bacteriologically positive when at least $10^{3} \mathrm{cfu} / \mathrm{mL}$ of the same type were isolated (Watkins et al., 1991).

Apparently normal milk samples with at least $10^{3}$ $\mathrm{cfu} / \mathrm{mL}$ of the same pathogen were considered bacteriologically positive. Sheep whose udders were without clinical abnormalities and whose milk was bacteriologically positive were considered to have subclinical mastitis and defined as infected.

Isolated pathogens were classified as environmental (E. coli, P. aeruginosa), CNS (Staphylococcus chromogenes, Staphylococcus xylosus, Staphylococcus lentus, Staphylococcus epidermidis, Staphylococcus capitis, Staphylococcus warneri, Staphylococcus auricularis, Staphylococcus saprophyticus, Staphylococcus hominis, Staphylococcus simulans, Staphylococcus caprae, Staphylococcus sciuri), streptococci (Enterococcus avium, Aerococcus viridans, Streptococcus suis, Enterococcus durans, Streptococcus uberis), and Enterobacteriaceae. In no case was Staph. aureus, the main contagious pathogen, isolated. Samples yielding $>2$ bacterial species were considered to be contaminated (IDF, 1981). Based on this criterion, 323 milk samples were excluded from the study. The diagnosis of IMI was confirmed according to the main pathogen when 2 different species were present. In accordance with Pitkälä et al. (2004), 
the diagnosis in these cases was prioritized by pathogen as follows: Streptococcus uberis/Streptococcus spp. > CNS $>$ Enterococcus spp. $>$ A. viridans. Glands with subclinical mastitis from which a pathogen was isolated received no chemotherapeutic treatment and were eligible for sampling at subsequent sampling periods.

\section{Leukocyte Differential Count in Milk and Blood}

Leukocyte differential count was performed according to Koess and Hamann (2008), as modified by Albenzio and Caroprese (2011) for ewe milk. Anti-bovine CD5 conjugated to R-Phycoerythrin (RPE) (MCA2215PE, Serotec, Oxford, UK) was used for the detection of lymphocytes, mouse anti-bovine CD11b conjugated to fluorescein isothiocyanate (FITC; MCA1425F, Serotec) for the detection of PMNL, and mouse antihuman CD14 conjugated to RPE-Alexa Fluor 647 (MCA 1568P647T, Serotec) for the detection of macrophages. Samples were acquired by flow cytometry (Cell Lab Quanta SC, Beckman Coulter Inc., Fullerton, CA). Linear amplification of the forward scatter and side scatter light signals was set with logarithmic amplification of the fluorescence signals. An excitation wavelength of $488 \mathrm{~nm}$ was used. Milk lymphocytes, macrophages, and PMNL were selected for analysis by gating on the forward scatter and side scatter dot plot. Fluorescence of FITC, RPE, and RPE-Alexa Fluor 647 were measured at 519,578, and $668 \mathrm{~nm}$, respectively. Approximately 10,000 events were collected for each sample; fluorescence (FL)1 versus FL2 was then used to determine the proportions of CD14/CD11b and CD14/ CD5. The proportion of nonviable milk cells was determined by staining cell pellets, suspended in $200 \mu \mathrm{L}$ of PBS, with $50 \mu \mathrm{L}$ of propidium iodide (PI, P4864, Sigma-Aldrich, Milan, Italy; $4 \mu \mathrm{L} / \mathrm{mL}$ ) and incubating for $15 \mathrm{~min}$. Samples were acquired by flow cytometry (FC; Cell Lab Quanta SC, Beckman Coulter Inc.) and fluorescence was measured at $617 \mathrm{~nm}$.

During each milk sampling, blood samples $(10 \mathrm{~mL})$ were collected in heparinized vacuum tubes from the jugular vein, and $100 \mu \mathrm{L}$ of whole blood was simultaneously labeled with $10 \mu \mathrm{L}$ of mouse anti-bovine CD5 conjugated to RPE (Serotec) for the detection of lymphocytes, $10 \mu \mathrm{L}$ of mouse anti-bovine CD11b conjugated to FITC (Serotec) for the detection of PMNL, and $5 \mu \mathrm{L}$ of mouse anti-human CD14 conjugated to RPE-Alexa Fluor 647 (Serotec) for the detection of monocytes and incubated at $4^{\circ} \mathrm{C}$ for $20 \mathrm{~min}$ in the dark.

The percentage of lymphocyte T-helper $\left(\mathrm{CD}^{+}\right)$and lymphocyte T-cytotoxic $\left(\mathrm{CD}^{+}\right)$cells was determined in milk and blood samples according to Caroprese et al. (2010). Briefly, cells were lysed (Lysing Solution IOTest 3 10× Concentrate, Beckman Coulter Inc.) and washed twice by centrifugation in PBS; milk cells were centrifuged for $4 \mathrm{~min}$ at $350 \times g$ and $10^{\circ} \mathrm{C}$, and blood cells for 5 min at $150 \times g$ at room temperature. The samples were analyzed by flow cytometry and data were acquired on a FACSort flow cytometer (Cell Lab Quanta SCTM, Beckman Coulter Inc.). Fluorescence of FITC and RPE were measured through 530/30 and $585 / 42$ band pass filters, respectively, and FL1 versus FL2 were then used to determine the proportions of $\mathrm{CD} 4^{+} / \mathrm{CD} 8^{+}$.

\section{Determination of Interleukins in Milk}

For each milk sample, concentrations of IL-8, IL10, IL-12, IL-1 $\beta$, and tumor necrosis factor (TNF)- $\alpha$ were measured. The detection of IL-1 $\beta$ in whey was determined by capture ELISA performed on 96-well microtiter plates according to Caroprese et al. (2006). Whey samples were read against a standard curve (y = $0.996 \mathrm{x}-0.0114 ; \mathrm{R}^{2}=99.99 \%$ ), obtained using scalar dilution of recombinant ovine IL-1 $\beta$ (Serotec). Data were expressed as nanograms of IL-1 $\beta$ per milliliter.

Production of IL-10 and IL-12 in whey was determined using a pair of bovine-specific monoclonal antibodies against IL-10 and IL-12 (Serotec) in a sandwich capture ELISA described in detail by Kwong et al. (2002). The ELISA was standardized using biologically active recombinant ovine IL-10 expressed in Chinese hamster ovary cells using the glutamine synthase expression vector (Lonza, Blackley, UK). Production of recombinant ruminant cytokines using this system was described in Graham et al. (1995) and Entrican et al. (1996). Recombinant ovine IL-10 was provided by the Biotechnology and Biological Sciences Research Council / Rural and Environment Research and Analysis Directorate (BBSRC/RERAD) Immunological Toolbox. The standard curve obtained for IL-10 was y $=0.007271+$ $0.0065 \mathrm{x}+0.0065 \mathrm{x}^{2}, \mathrm{R}^{2}=99.09 \%$. The IL-12 standard curve was $\mathrm{y}=0.000511 \mathrm{x}+0.0275, \mathrm{R}^{2}=99 \%$ ) and was made up by bovine recombinant protein purchased from Kingfisher Biotech Inc. (St. Paul, MN). Data on IL-10 were expressed as biological units/mL according to Kwong et al. (2002).

The detection of TNF- $\alpha$ in whey was determined by sandwich ELISA performed on 96-well microtiter plates, according to Hope et al. (2003) by using a bovine monoclonal antibody specific for TNF- $\alpha$ (Serotec). Data were expressed as picograms of TNF- $\alpha$ per milliliter, and the standard curve was $\mathrm{y}=0.000216 \mathrm{x}-0.119$, $\mathrm{R}^{2}=97.7 \%$ ), made up by bovine $\mathrm{TNF}-\alpha$ recombinant protein (Serotec).

The detection of ovine IL- 8 was determined with a standard sandwich ELISA performed on 96-well microtiter plates according to Caswell et al. (1998) and 
modified by Herndon et al. (2010) using monoclonal anti-ovine IL-8 antibody (Serotec), in coating buffer carbonate ( $\mathrm{pH}$ 9.6), diluted 1:5,000 (100 $\mathrm{L} \mathrm{L} /$ well). Nonspecific bindings were blocked with bovine $\mathrm{Na}$ caseinate $(1 \%$ in PBS, $\mathrm{pH} 7.2)$ at $37^{\circ} \mathrm{C}$ for $45 \mathrm{~min}$. Ovine IL-8 evaluation was a qualitative assay, and the data were expressed in optical density units.

\section{Determination of Endogenous Proteolytic Enzymes}

Plasmin (PL), elastase, and cathepsin D activities were determined according to the procedures described by Albenzio et al. (2009). One unit of PL was defined as the amount of enzyme that produced a change in absorbance at $405 \mathrm{~nm}$ of 0.1 in $60 \mathrm{~min}$. One unit of catepsin D was defined as the amount of enzyme that produced a change in absorbance at $280 \mathrm{~nm}$ of 1 in 1 min. One unit of elastase was defined as the amount of enzyme that hydrolyzed $1 \mu \mathrm{moL}$ of substrate in $1 \mathrm{~min}$.

\section{Statistical Analysis}

All variables were tested for normal distribution using the Shapiro-Wilk test (Shapiro and Wilk, 1965). Data were processed using ANOVA (SAS Institute, 2011). The variation due to SCC and pathogenic bacteria in milk and their interaction was tested. Effects of pathogenic bacteria (E. coli, P. aeruginosa, Staph. chromogenes, Staph. xylosus, Staph. epidermidis, Staph. warneri, Staph. saprophyticus, Staph. hominis, A. viridans, Strep. suis, E. durans, and Strep. uberis) on differential leukocyte count, interleukin, and endogenous proteolytic enzymes were tested. Where significant effects were found $(P<0.05)$, the Student $t$-test was used to locate significant differences between means. Linear simple correlations between leukocyte cell types, endogenous proteolytic enzymes, and cytokines were also studied.

\section{RESULTS AND DISCUSSION}

\section{Immune Competence of the Ewe Mammary Gland}

The effects of SCC and milk pathogens on leukocyte population and nonviable PMNL in blood and ewe milk samples are reported in Table 1. No differences were found in the PMNL and lymphocyte percentages across SCC classes and pathogenic bacteria, whereas an effect of the interaction between SCC and pathogenic bacteria was found for monocyte cells. In blood samples from infected ewes, monocytes increased with SCC. Differences between infected and noninfected ewes were reported only for SC>2000, with higher monocyte counts in infected ewes. Blood leukocyte populations were in line with ranges reported for sheep (Kramer, 2000). Polymorphonuclear neutrophilic leukocytes and macrophages showed increasing levels from SC300 to SC $>2000$, concomitant with a decrease in lymphocytes. Changes in the leukocyte population highlighted that lymphocytes were the predominant population, with over $50 \%$ of ewe milk samples ascribed to SC300 and comparable percentages of lymphocytes and PMNL in SC500 being observed. Finally, PMNL became the main population in the SC1000, SC2000, and SC $>2000$ classes. It has been reported that lymphocytes are the predominant population in healthy mammary glands of dairy cows (Schwarz et al., 2011).

In the mammary gland, the number and distribution of leukocytes are important for successful udder defense against invading pathogens; lymphocytes, macrophages, and PMNL play an important role in inflammatory responses within the mammary gland. The PMNL are phagocytic cells with a specific bactericidal function; they possess an arsenal of enzymes and chemical agents, which can destroy engulfed bacteria. Macrophages are also phagocytes and can ingest bacteria, cellular debris, and accumulated milk components, whereas lymphocytes are responsible for immune memory and antibody production (Kelly, 2003). Macrophage cells increased in SCC classes with a different behavior between uninfected and infected ewes: milk samples without pathogenic bacteria showed an increase from SC1000 to SC2000, whereas the same parameter increased linearly with SCC in milk samples containing pathogenic bacteria. Resident macrophages ingest bacteria and secrete unidentified mediators that, in the next step, stimulate migration of neutrophils (Koess and Hamann, 2008). Thus, SCC is low in the very first stage of inflammation (Rainard and Riollet, 2006). Overall, milk samples with $\mathrm{SCC}>1,000,000$ cells $/ \mathrm{mL}$ showed differences in leukocytes differential count between uninfected and infected ewes, as was seen by the higher percentages of PMNL and macrophages and lower percentages of lymphocytes in infected animals. Differences in leukocyte differential count between uninfected and infected ewes confirm that an inflammatory process against invading pathogens exists in ewe udders with $\mathrm{SCC}>1,000,000$ cells/mL. In contrast, the increased SCC in uninfected udders is not indicative of an ongoing inflammatory process, but can be considered evidence of the resolution of a previous inflammatory process.

Nonviable PMNL cells were influenced by SCC, being highest in ewe milk samples with SCC $<300,000$ cells $/ \mathrm{mL}$, irrespective of the presence of pathogens. In contrast, starting from SCC $>500,000$ cells $/ \mathrm{mL}$, nonviable PMNL were higher in uninfected ewes than in infected ewes. Mehrzad et al. (2004) reported that 
Table 1. Effects of SCC and pathogenic bacteria on differential leukocyte cell type in individual ewe blood and milk samples

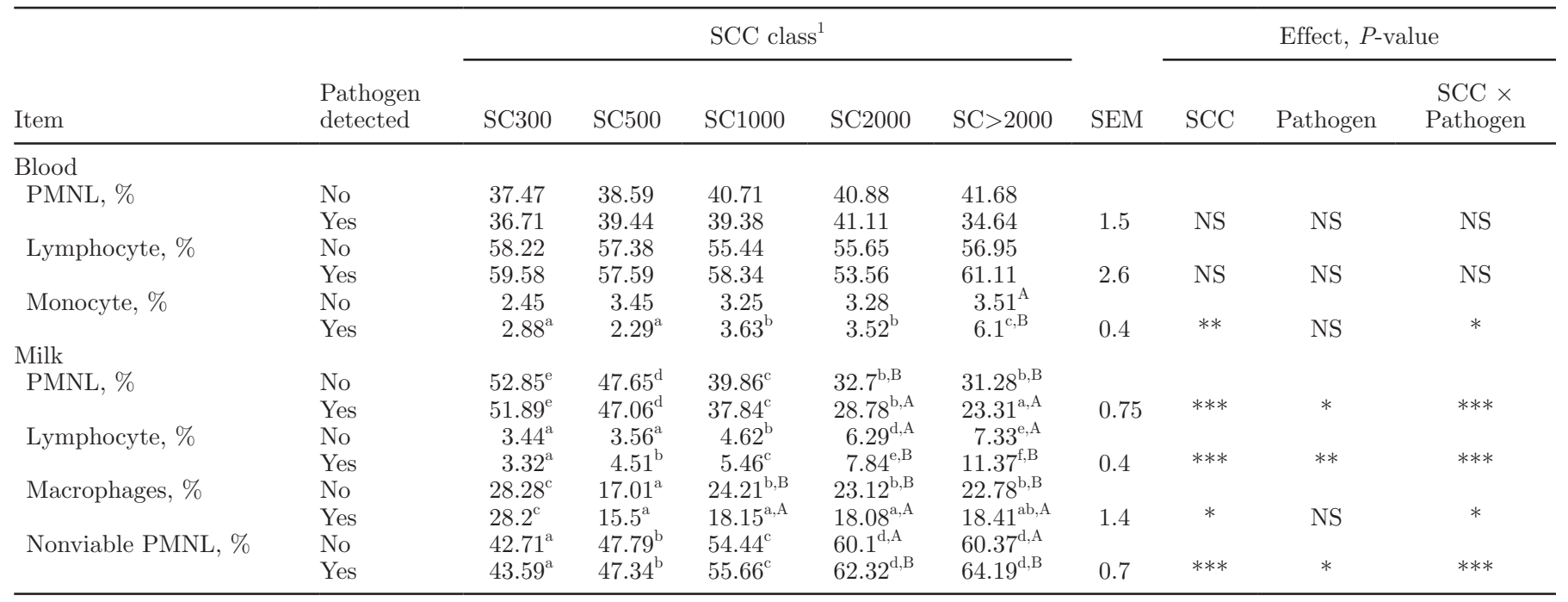

${ }^{\mathrm{a} e}$ Means within a row with different superscripts differ $(P<0.05)$.

${ }^{\mathrm{A}, \mathrm{B}}$ Means within a column with different superscripts differ $(P<0.05)$.

${ }^{1}$ SC300: <300,000 cells/mL; SC500: from 300,000 to 500,000 cells/mL; SC1000: from 501,000 to 1,000,000 cells/mL; SC2000: from 1,001,000 to 2,000,000 cells/mL; SC>2000: >2,000,000 cells/mL.

${ }^{*} P<0.05$; ${ }^{*} P<0.01 ;{ }^{* * *} P<0.001$.

the PMNL recruited in the udder during the transition from normal to high SCC milk are relatively young and show slow apoptosis, whereas the PMNL population resident in the udder is old and not very efficient. In ewe milk samples with $\mathrm{SCC}<500,000$ cells $/ \mathrm{mL}$, Albenzio and Caroprese (2011) reported a high positive correlation between PMNL and nonviable PMNL cells. However, resident PMNL in cow's milk with low SCC modulate the initial steps of dynamic immune defense of the udder (Mehrzad et al., 2004). When nonviable PMNL were evaluated, differences between infected and noninfected ewes emerged beginning at 500,000 cells $/ \mathrm{mL}$, evidencing changes in the recruitment of PMNL in the udder. In uninfected ewes giving milk with SCC $>1,000,000$ cells $/ \mathrm{mL}$, the predominance of the PMNL population together with a higher percentage of nonviable PMNL may be explained by the successful outcome from pathogen infection. Thus, we can hypothesize that milk samples with $\mathrm{SCC}>1,000,000$ cells $/ \mathrm{mL}$ from uninfected ewes are destined to have a decrease in total SCC and to have a lower percentage of PMNL and macrophages cells. Therefore, nonviable PMNL could represent a useful parameter to monitor changes in leukocyte populations in relation to the inflammatory status of the ewe mammary gland.

\section{Cytokine Pattern in Ewe Milk}

The effects of SCC and pathogenic bacteria on levels of TNF- $\alpha$, IL-8, IL-1 $\beta$, IL-10, and IL-12 in individual ewe milk samples are reported in Table 2. Levels of TNF- $\alpha$ and IL-12 were always higher in ewe milk samples when pathogenic bacteria were isolated from SCC. Interleukin-8 was influenced by both SCC and pathogenic bacteria, being higher in ewe milk samples with higher SCC levels, whereas samples with pathogenic bacteria displayed higher levels of IL-8 in SC300 and $\mathrm{SC}>2000$.

In the early phase of inflammation, the production and release of TNF- $\alpha$, IFN- $\gamma$, and interleukins (Wellnitz et al., 2010) are observed. Cytokines not only regulate local inflammatory reactions by cell-to-cell communication, but may also gain access to circulation and induce systemic effects. In the presence of pathogens, macrophages release IL- 8 and TNF- $\alpha$, which results in PMNL recruitment from blood to milk (Le Maréchal et al., 2011). Monocyte and dendritic cells are believed to be the major sources of IL-12; neutrophils can produce IL-12 due to their presence in high numbers at sites of infection, thus neutrophils are thought to be a relevant source of this cytokine during the inflammatory process (Bannerman, 2009). The increase in endothelial permeability also induces the transfer of other blood components from blood to milk associated with specific immune reactions such as T-cell population and endogenous protease and lipase enzymes. The absence of IL-10 changes in the presence of pathogenic bacteria can be ascribed to the absence of a clear association between the magnitude of IL-10 response and the bacterial wall type (i.e., gram-positive, gram-negative, 
Table 2. Effects of SCC and pathogenic bacteria on tumor necrosis factor (TNF)- $\alpha$, IL-8, IL-1ß, IL-10, and IL-12 in individual ewe milk samples

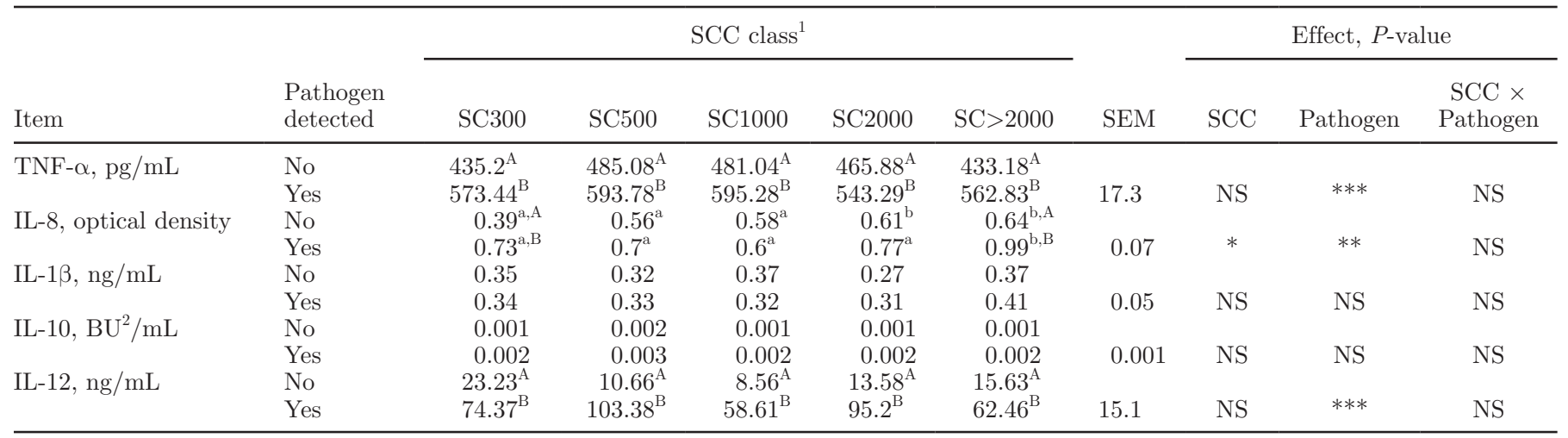

$\overline{a, b}$ Means within a row with different superscripts differ $(P<0.05)$.

${ }^{\mathrm{A}, \mathrm{B}}$ Means within a column with different superscripts differ $(P<0.05)$.

${ }^{1}$ SC300: $<300,000$ cells/mL; SC500: from 300,000 to 500,000 cells/mL; SC1000: from 501,000 to 1,000,000 cells/mL; SC2000: from 1,001,000 to 2,000,000 cells/mL; SC>2000: >2,000,000 cells/mL.

${ }^{2}$ Biological unit (Kwong et al., 2000).

${ }^{*} P<0.05 ;{ }^{* *} P<0.01 ;{ }^{* * *} P<0.001$.

wall-less) reported by Bannerman (2009). The same author reported that IL-10 induction is absent or delayed in cows with persistent concentrations of Staph. aureus, Strep. uberis, and Mycobacterium bovis in milk.

\section{$C D 4^{+}$and $C D 8^{+} T$ Lymphocytes in Ewe Milk and Blood}

The effects of SCC class and pathogenic bacteria on percentages of $\mathrm{CD}^{+}$and $\mathrm{CD} 8^{+} \mathrm{T}$ lymphocytes in ewe blood and milk samples are reported in Table 3. An interaction effect of SCC and pathogen was found on $\mathrm{CD}^{+}$and $\mathrm{CD}^{+}$cells in milk; milk samples showed a reduction of these parameters along with an increase of SCC: starting from SCC $>1,000,000$ cells $/ \mathrm{mL}$, a higher level of $\mathrm{CD} 4^{+}$was found in the presence of pathogens. In blood, $\mathrm{CD} 4^{+}$and $\mathrm{CD} 8^{+}$cells were not affected by the tested effects. The $\mathrm{T}$ cells play a central role in cellular and humoral immunity contributing to immune homeostasis of the host. On the basis of specialized cell markers on their surface, $\mathrm{T}$ cells are composed of a variety of subpopulations such as $\mathrm{CD} 2^{+}, \mathrm{CD} 4^{+} \mathrm{T}$ helper (Th) cells, $\mathrm{CD}^{+}$cytotoxic $\mathrm{T}$ cells, $\gamma / \delta \mathrm{T}$ cells, and memory T cells (Mehrzad and Zhao, 2008). The percentage of $\mathrm{CD}^{+}$and $\mathrm{CD} 8^{+}$detected in blood are in line with previous results in ewes (Caroprese et al., 2010 ) and lead to a $\mathrm{CD} 4^{+} / \mathrm{CD} 8^{+}$ratio $<2$, suggesting an unbalanced distribution between T-cell subsets. It is worth noting that the relative proportions of $\mathrm{CD} 4^{+}$ and $\mathrm{CD} 8^{+}$were opposite in blood and milk so that the $\mathrm{CD}^{+} / \mathrm{CD}^{+}$ratio was always lower in blood than in milk. In mammary gland secretions, the $\mathrm{CD} 8^{+}$lymphocytes are able to suppress the proliferative response of
$\mathrm{CD}^{+}$cells (Park et al., 1993). However, the $\mathrm{CD}^{+} /$ $\mathrm{CD} 8^{+}$ratio reported for blood and milk are in accordance with those found by Persson-Waller and Colditz (1998) for lactating ewes.

In infected ewes giving milk with $\mathrm{SCC}>1,000,000$ cells $/ \mathrm{mL}$, a higher $\mathrm{CD} 4^{+} / \mathrm{CD} 8^{+}$ratio was observed, suggesting that the presence of pathogens induced activation both of $\mathrm{CD} 4^{+}$and $\mathrm{CD} 8^{+}$in ewe milk. During the early immune response of the mammary gland to bacterial pathogens, the elevated $\mathrm{T}$ cells in the gland mainly resulted from the increase in activated $\mathrm{CD} 8^{+}$ cells. Changes in proportions of leukocyte subpopulation in ewe udders may influence immunological responsiveness to udder infection.

\section{Prevalence and Etiology of IMI in Ewes}

The prevalence of subclinical mastitis in small ruminants has been estimated at 5 to $30 \%$ or even higher but only limited data are available regarding the incidence of IMI in the literature (Contreras et al., 2007). About $50 \%$ of the 1,500 milk samples analyzed were bacteriologically positive. Among the bacteriological positive samples, CNS represented 21\%, Streptococcus spp. 19\%, E. coli 18\%, P. aeruginosa 21\%, and Enterobacteriaceae $9 \%$.

Percentages of bacterial species identified in individual ewe milk samples with respect to SCC class are reported in Table 4. The incidence of E. coli was $>10 \%$ in SC300, SC500, and SC>2000, whereas it was about $6 \%$ in SC2000. Pseudomonas aeruginosa was isolated in ewe milk samples from all SC classes with an incidence of $13 \%$ in milk samples with $>1,000,000$ cells $/ \mathrm{mL}$, 
Table 3. Effects of SCC and pathogenic bacteria on $\mathrm{CD} 4^{+}$and $\mathrm{CD} 8^{+}$in individual ewe milk and blood samples

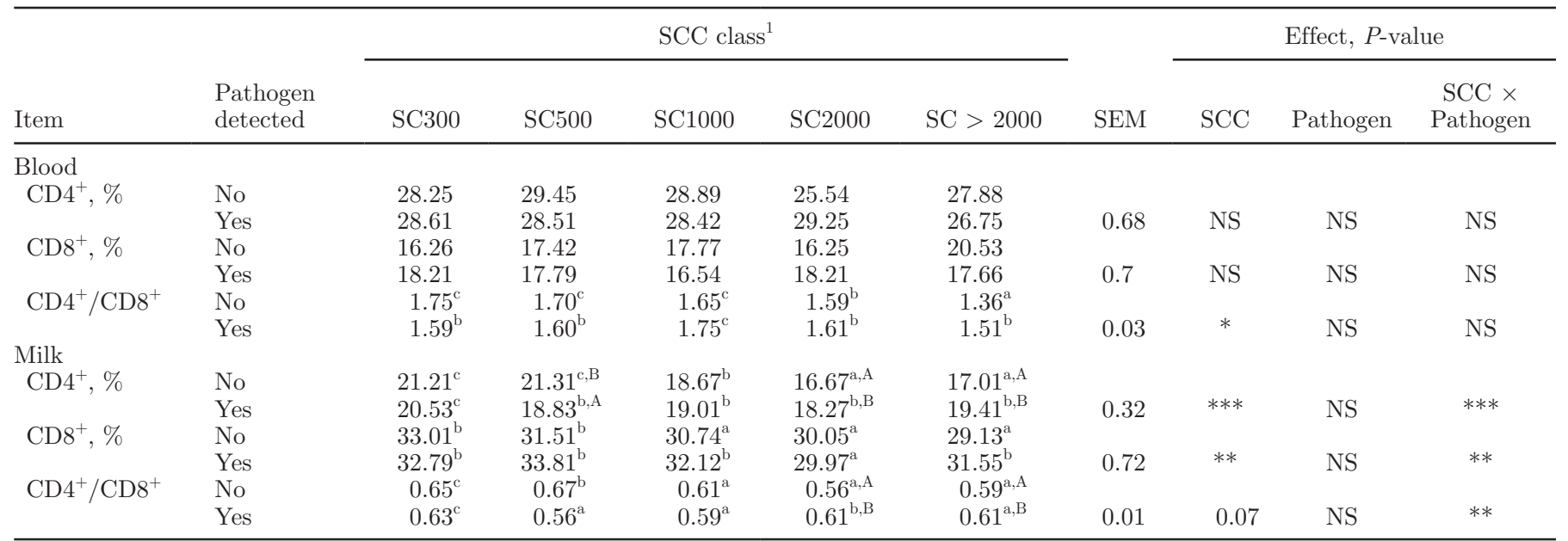

${ }^{\mathrm{a}-\mathrm{c}}$ Means within a row with different superscripts differ $(P<0.05)$.

${ }^{\mathrm{A}, \mathrm{B}}$ Means within a column with different superscripts differ $(P<0.05)$.

${ }^{1}$ SC300: <300,000 cells/mL; SC500: from 300,000 to 500,000 cells/mL; SC1000: from 501,000 to 1,000,000 cells/mL; SC2000: from 1,001,000 to 2,000,000 cells $/ \mathrm{mL} ; \mathrm{SC}>2000:>2,000,000$ cells $/ \mathrm{mL}$.

${ }^{*} P<0.05 ;{ }^{* *} P<0.01 ;{ }^{* * *} P<0.001$.

and about $9 \%$ in milk samples with $<500,000$ cells/ $\mathrm{mL}$. Samples with SCC between 500,000 and 1,000,000 cells $/ \mathrm{mL}$ had no cases of $E$. coli and a lower incidence of $P$. aeruginosa. A high prevalence of CNS was detected in SC1000, whereas it was low in SC>2000; an inci- dence of about $10 \%$ was reported in SC300, SC500, and SC2000. Streptococcus spp. showed a high prevalence in SC500 and SC>2000 classes and a low prevalence in SC1000; and Enterobacteriaceae were detected in SC500 and SC1000 classes. Among CNS, the most rep-

Table 4. Prevalence (\%) and etiology of intramammary infections in ewe milk samples with different SCC

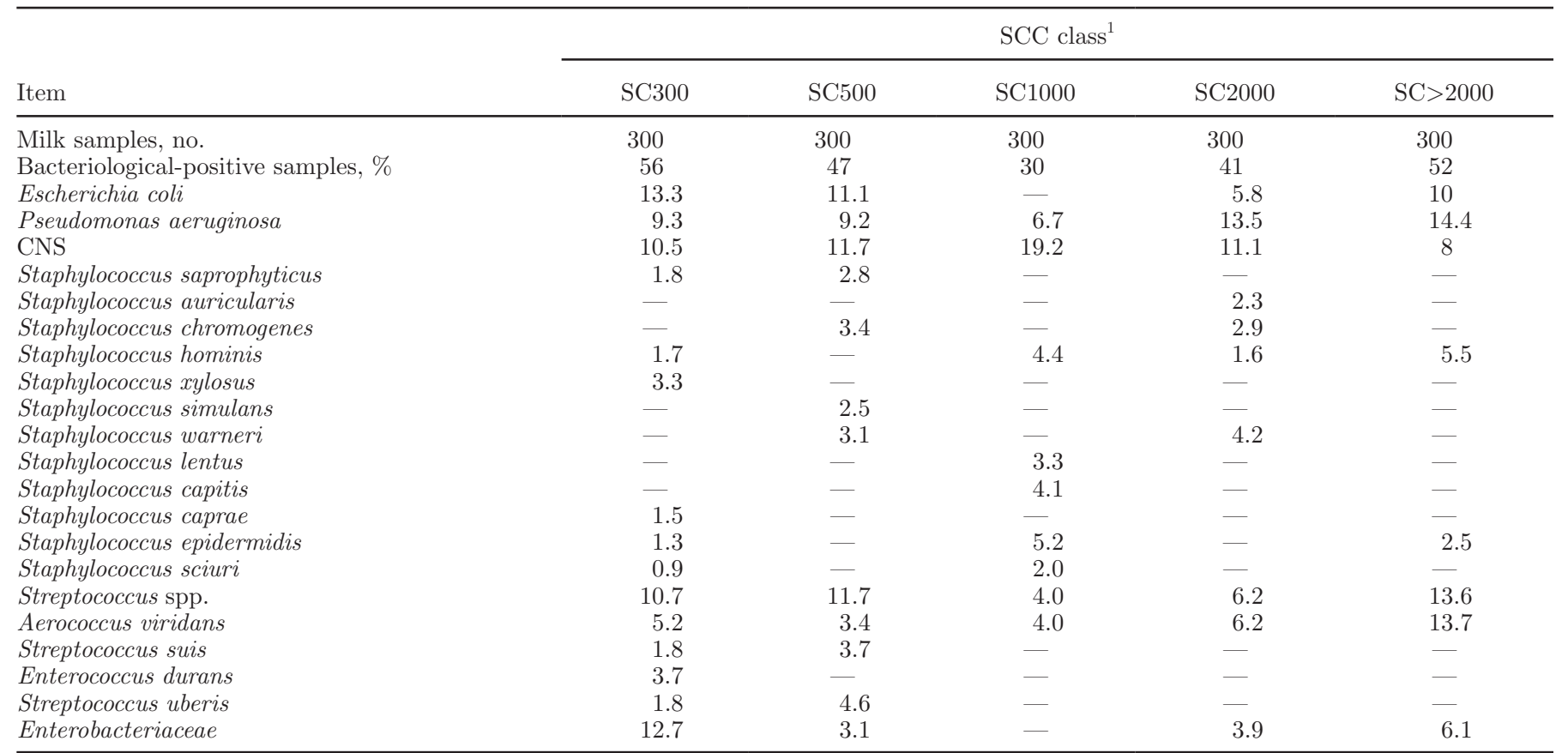

${ }^{1}$ SC300: <300,000 cells/mL; SC500: from 300,000 to 500,000 cells/mL; SC1000: from 501,000 to 1,000,000 cells/mL; SC2000: from 1,001,000 to 2,000,000 cells/mL; SC>2000: $>2,000,000$ cells/mL. 


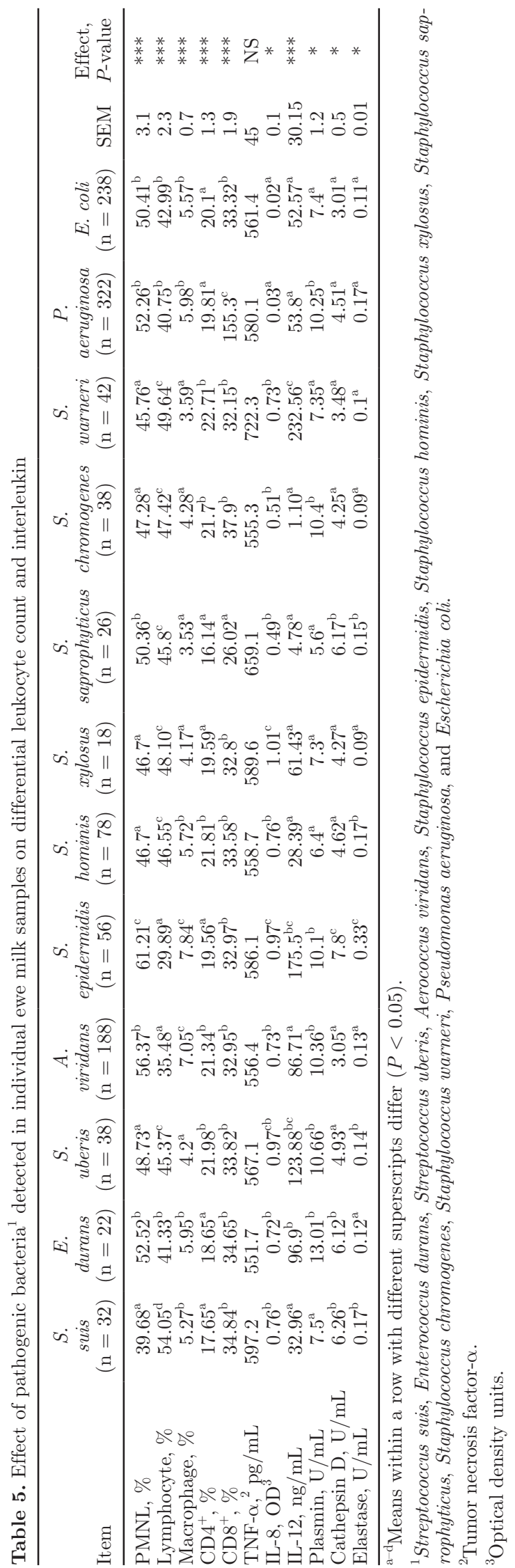

resented were Staph. hominis, Staph. warneri, Staph. epidermidis, Staph. chromogenes, Staph. saprophyticus, and Staph. xylosus, whereas among streptococci $A$. viridans, Strep. uberis, and Strep. durans were found. Pathogens were differently distributed in SC classes: A. viridans were widely spread among classes, whereas Staph. xylosus was only found in SC300; Staph. warneri and Staph. chromogenes were only found in SC500 and SC2000; Staph. saprophyticus and Strep. uberis were only found in SC300, SC500, and SC2000; and finally S. epidermidis was only found in SC300 and SC1000. It is worth noting that the aforementioned pathogens were predominantly isolated from ewe milk samples with SCC $<500,000$ cells $/ \mathrm{mL}$.

Differential leukocyte count, $\mathrm{CD} 4^{+}, \mathrm{CD}^{+}$, and cytokine levels in ewe milk samples infected with different pathogens are reported in Table 5. Leukocyte differential count was affected by the type of pathogens isolated showing that Strep. durans, A. viridans, Staph. saprophyticus, P. aeruginiosa, and E. coli showed a percentage of PMNL higher than $50 \%$ and Staph. epidermidis showed a percentage higher than $60 \%$. Milk samples containing Staph. epidermidis and A. viridans showed the highest percentage of macrophages and lowest percentage of lymphocytes.

Ewe milk samples containing Strep. uberis, A. viridans, Staph.hominis, Staph. chromogenes, and Staph. warneri showed the highest $\mathrm{CD} 4^{+}$level, whereas $\mathrm{CD} 8^{+}$ was the highest in samples containing $P$. aeruginosa and the lowest in samples with Staph. saprophyticus.

Samples containing Staph. warneri showed the highest IL-12 level, whereas samples containing $A$. viridans, Staph. hominis, Staph. xylosus, Staph. saprophyticus, Staph. chromogenes, P. aeruginosa, and E. coli had the lowest level of IL-12. Streptococcus uberis had an immunological pattern characterized by the highest level of IL-12 and by a percentage of PMNL $<50 \%$, suggesting a relationship between cytokines and PMNL, the former being able to persist at high levels after infection with the latter turning to lower values despite the presence of bacteria in milk (Contreras et al., 2007). Furthermore, IL-8 showed the highest value in milk infected with Strep. uberis; accordingly, the concentration of IL-8 was significantly elevated in mammary secretions from challenged mammary glands infected with Strep. uberis (Rambeaud et al., 2003).

Aerococcus viridans showed higher values of PMNL and macrophages and the lowest values of cytokines. The presence of cytokines and neutrophils diverges as the infection progressed (Winter and Colditz, 2002). In particular, IL-8 has the ability to be rapidly internalized by mammary cells; therefore, it is possible that this cytokine is produced but not detected in mammary secretion (Rambeaud et al., 2003). Staphylococcus 
epidermidis resulted in higher PMNL and macrophages together with IL-8 and IL-12; in addition to its role in attracting neutrophils to the sites of infections, IL-8 enhances the functioning of these cells (Bannerman, 2009).

\section{Endogenous Proteolytic Enzymes}

The effects of SCC and pathogenic bacteria on PL, cathepsin D, and elastase activity are reported in Table 6. It is known that indigenous proteolytic enzymes, such as the plasmin-plasminogen system, elastase, and cathepsin are mainly associated with leukocytes and are involved in milk casein breakdown. Plasmin activity was influenced by both SCC and pathogenic bacteria, showing an increase with increasing SCC levels and always being higher in milk samples containing pathogenic bacteria. Cathepsin D was affected by SCC and interaction between SCC and pathogen; the increase of this enzyme was observed starting from SC2000 in samples from noninfected ewes and starting from SC500 in samples from infected ewes. However, the isolation of pathogenic bacteria resulted in a higher level of cathepsin D starting from the SC500 class. Elastase contributed minimally to total endogenous protease activity and was influenced by the interaction between SCC and pathogenic bacteria. Within milk samples containing pathogenic bacteria, elastase activity was higher starting from the SC1000 class. The increase of these enzymes during IMI is linked to an increase in PMNL and can be explained by 2 mechanisms: (1) the proteases can be released by vesicles such as lysosomes from PMNL and caseins, and (2) fat globules can be endocytosed by PMNL, with the degradation products being released into the milk after intracellular digestion (Le Roux et al., 2003). The release of proteases increases with SCC and may vary depending on the pathogen. No data are available regarding the role of each pathogenic species on leukocyte protease release and activity in ewe milk. This has only been studied in E. coli mastitis, in which the level or activity of endogenous proteases increases and may explain caseinolysis in cow's milk (Moussaoui et al., 2002).

In this study, PL activity was higher in milk samples from ewes infected by E. durans, Strep. uberis, A. viridans, Staph. epidermidis, Staph. chromogenes, and P. aeruginosa, whereas cathepsin D and elastase displayed the highest value in milk samples from ewes infected by Staph. epidermidis (Table 5). In milk samples containing Staph. epidermidis, the highest level of IL- 8 could be responsible for the higher cathepsin D activity as confirmed by the positive correlation between these 2 parameters $(\mathrm{r}=0.97 ; P<0.05)$. Indeed, the cytokine profile appears to be pathogen-specific, suggesting that it may have a different effect on protease gene transcription; the activity of elastase and cathepsin is promoted by proinflammatory cytokines at the transcriptional level (Le Roux et al., 2003; Haddadi et al., 2006). The higher level of macrophages found in ewe milk samples containing Staph. epidermidis and A. viridans could be partly responsible for the higher activity of PL as confirmed by the positive correlation between these parameters $(\mathrm{r}=0.98 ; P<0.001$ and $\mathrm{r}$ $=0.88 ; P<0.001$, respectively). In ewe bulk milk, the increased conversion of zymogen to PL can result from the increased production of urokinase-type activators by ovine macrophages and neutrophils (Politis et al., 2002).

\section{CONCLUSIONS}

The associations between somatic cells, cytokines, endogenous proteolytic enzymes, and pathogenic bacteria can be used to better understand the pathogenesis

Table 6. Effects of SCC and pathogenic bacteria on endogenous proteolytic enzymes in individual ewe milk samples

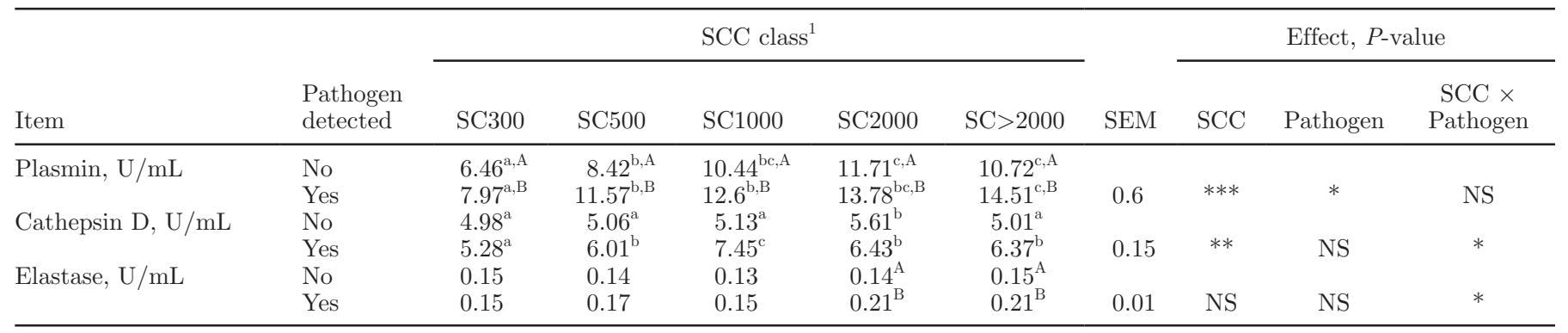

${ }^{\mathrm{a}-\mathrm{c}}$ Means within a row with different superscripts differ $(P<0.05)$.

${ }^{\mathrm{A}, \mathrm{B}}$ Means within a column with different superscripts differ $(P<0.05)$.

${ }^{1}$ SC300: <300,000 cells/mL; SC500: from 300,000 to 500,000 cells/mL; SC1000: from 501,000 to 1,000,000 cells/mL; SC2000: from 1,001,000 to 2,000,000 cells/mL; SC>2000: $>2,000,000$ cells $/ \mathrm{mL}$.

${ }^{*} P<0.05 ;{ }^{* *} P<0.01 ;{ }^{* * *} P<0.001$. 
of subclinical mastitis in ewes and the effect on the immune response of ewe mammary gland. Milk samples with $\mathrm{SCC}>1,000,000$ cells $/ \mathrm{mL}$ showed differences in leukocyte differential count between uninfected and infected ewes as evidenced by higher percentages of PMNL and macrophages and lower percentages of lymphocytes in infected ewes. Furthermore, nonviable PMNL could represent a useful parameter to monitor changes in leukocyte population in relation to the inflammatory status of the mammary gland. Changes in proportions of leukocyte subpopulations $\left(\mathrm{CD} 4^{+}\right.$and $\left.\mathrm{CD} 8^{+}\right)$in ewe udders may influence immunological responsiveness to udder infection. Tumor necrosis factor- $\alpha$, IL- 8 , and IL12 were able to discriminate between infected and noninfected ewes and showed a pathogen-specific profile. Endogenous proteolytic enzymes resulted in increased activity in the presence of pathogenic bacteria and exhibited differences along with cytokine activation.

\section{ACKNOWLEDGMENTS}

The authors thank Claire Moore (University of Foggia, Italy) for assistance for English revision.

\section{REFERENCES}

Albenzio, M., and M. Caroprese. 2011. Differential leukocyte count for ewe milk with low and high somatic cell count. J. Dairy Res. $78: 43-48$.

Albenzio, M., A. Santillo, M. Caroprese, F. d'Angelo, R. Marino, and A. Sevi. 2009. Role of endogenous enzymes in proteolysis of sheep milk. J. Dairy Sci. 92:79-86.

Albenzio, M., A. Santillo, M. Caroprese, L. Schena, D. E. Russo, and A. Sevi. 2011. Composition, indigenous proteolytic enzymes and coagulating behaviour of ewe milk as affected by somatic cell count. J. Dairy Res. 78:442-447.

Bannerman, D. D. 2009. Pathogen-dependent induction of cytokines and other soluble inflammatory mediators during intramammary infection of dairy cows. J. Anim. Sci. 87:10-25.

Caroprese, M., M. Albenzio, G. Annicchiarico, and A. Sevi. 2006 Changes occurring in immune responsiveness of single- and twin-bearing Comisana ewes the transition period. J. Dairy Sci. $89: 562-568$.

Caroprese, M., M. Albenzio, A. Marzano, L. Schena, G. Annicchiarico, and A. Sevi. 2010. Relationship between cortisol response to stress and behavior, immune profile, and production performances of dairy ewes. J. Dairy Sci. 93:2395-2403.

Caswell, J. L., D. M. Middleton, S. D. Sorden, and J. R. Gordon. 1998. Expression of the neutrophil chemoattractant interleukin-8 in the lesions of bovine pneumonic pasteurellosis. Vet. Pathol. $35: 124-131$.

Contreras, A., D. Sierra, A. Sanchez, J. C. Corrales, J. C. Marco, M. J. Paape, and C. Gonzalo. 2007. Mastitis in small ruminants. Small Rumin. Res. 68:145-153.

EEC. 1986. Council Directive 86/609/EEC of 24 November 1986 on the approximation of laws, regulations and administrative provisions of the Member States regarding the protection of animals used for experimental and other scientific purposes. Off. J. L358 (18/12/1993):1-28.

Entrican, G., D. Deane, M. MacLean, L. Inglis, J. Thomson, C. McInnes, and D. M. Haig. 1996. Development of a sandwich ELISA for ovine granulocyte/macrophage colony-stimulating factor. Vet. Immunol. Immunopathol. 50:105-115.

Graham, S. P., G. E. Jones, M. MacLean, M. Livingstone, and G. Entrican. 1995. Recombinant ovine interferon gamma inhibits the multiplication of Chlamydia psittaci in ovine cells. J. Comp. Pathol. 112:185-195.

Haddadi, K., C. Prin-Matheu, F. Moussaoui, G. C. Faure, F. Vangraenweghe, C. Burvenich, and Y. Le Roux. 2006. Polymorphonuclear neutrophils and Escherichia coli proteases involved in proteolysis of casein during experimental E. coli mastitis. Int. Dairy J. 16:639-647.

Herndon, C. N., W. J. Foreyt, and S. Srikumaran. 2010. Differential expression of interleukin- 8 by polymorphonuclear leukocytes of two closely related species, Ovis canadensis and Ovis aries, in response to Mannheimia haemolytica infection. Infect. Immun. 78:3578-3584.

Hope, J. C., A. O. Whelan, R. G. Hewinson, M. Vordermeier, and C. J. Howard. 2003. Maturation of bovine dentritic cells by lipopeptides. Vet. Immunol. Immunopathol. 95:31.

IDF (International Dairy Federation). 1981. Laboratory methods for use in mastitis work. IDF Bulletin No 132. FIL-IDF, Genève, Switzerland.

IDF (International Dairy Federation). 1995. Enumeration of somatic cells. Bulletin No 148A. FIL-IDF, Brussels, Belgium.

Kelly, A. L. 2003. Milk quality and udder health: Test methods and standards. Pages 1995-2001 in Encyclopedia of Dairy Sciences. H. Roginski, J. W. Fuquay, and P. F. Fox, ed. MPG Books Ltd., Bodmin, UK.

Koess, C., and J. Hamann. 2008. Detection of mastitis in the bovine mammary gland by flow cytometry at early stages . J. Dairy Res. $75: 225-232$.

Kramer, J. W. 2000. Normal hematology of cattle, sheep, and goats. Pages 1075-1084 in Schalm's Veterinary Hematology. 5th ed. B. F. Feldman, J. G. Zinkl, and N. C.Jain, ed. Lippincott Williams \& Wilkins, Philadelphia, PA.

Kwong, L. S., J. C. Hope, M. L. Thom, P. Sopp, S. Duggan, G. P. Bembridge, and C. J. Howard. 2002. Development of an ELISA for bovine IL-10. Vet. Immunol. Immunopathol. 85:213-223.

Le Maréchal, C., R. Thiéry, E. Vautor, and Y. Le Loir. 2011. Mastitis impact on technological properties of milk and quality of milk products-A review. Dairy Sci Technol. 91:247-282.

Le Roux, Y., F. Laurent, and F. Moussaoui. 2003. Polymorphonuclear proteolytic activity and milk composition change. Vet. Res. 34:629-645.

Mehrzad, J., L. Duchateau, and C. Burvenich. 2004. Viability of milk neutrophils and severity of bovine coliform mastitis. J. Dairy Sci. $87: 4150-4162$

Mehrzad, J., and X. Zhao. 2008. T lymphocyte proliferative capacity and $\mathrm{CD}^{+} / \mathrm{CD}^{+}$ratio in primiparous and pluriparous lactating cows. J. Dairy Res. 75:457-465.

Moussaoui, F., I. Michelutti, Y. Le Roux, and F. Laurent. 2002. Mechanisms involved in milk endogenous proteolysis induced by a lipopolysaccharide experimental mastitis. J. Dairy Sci. 85:2562-2570.

Oliver, S. P., and G. M. Pighetti. 2003. Environmental pathogens: Mastitis pathogens. Pages 1728-1734 in Encyclopedia of Dairy Sciences. H. Roginski, J. W. Fuquay, and P. F. Fox, ed. MPG Books Ltd., Bodmin, UK

Park, Y. H., L. K. Fox, M. J. Hamilton, and W. C. Davis. 1993 Suppression of proliferative response of BoCD4+ T lymphocytes by activated BoCD8+ T lymphocytes in the mammary gland of cows with Staphylococcus aureus mastitis. Vet. Immunol. Immunopathol. 36:137-151.

Persson-Waller, K., and I. G. Colditz. 1998. Expression of surface antigens on blood and mammary leukocyte in lactating and dry ewes. Vet. Immunol. Immunopathol. 62:273-278.

Pitkälä, A., M. Haveri, S. Pyörälä, V. Myllys, and T. Honkanen-Buzalski. 2004. Bovine mastitis in Finland 2001-Prevalence, distribution of bacteria, and antimicrobial resistance. J. Dairy Sci. 87:2433-2441. 
Politis, I., I. Bizelis, and E. Rogdakis. 2002. The urokinase-plasminogen activator system in ovine macro phages and neutrophils. Small Rumin. Res. 44:17-23.

Rainard, P., and C. Riollet. 2006. Innate immunity of the bovine mammary gland. Vet. Res. 37:369-400.

Rambeaud, M., R. A. Almeida, G. M. Pighetti, and S. P. Oliver. 2003. Dynamics of leukocytes and cytokines during experimentally induced Streptococcus uberis mastitis. Vet. Immunol. Immunopathol. 96:193-205.

SAS Institute. 2011. SAS User's Guide: Statistics. Version 9.2 ed. SAS Inst. Inc., Cary, NC.

Schwarz, D., U. S. Diesterbeck, S. König, K. Schlez, M. Zschöck, W. Wolter, and C. P. Czerny. 2011. Flow cytometric differential cell counts in milk for the evaluation of inflammatory reactions in clin- ically healthy and subclinically infected bovine mammary glands. J. Dairy Sci. 94:5033-5044.

Shapiro, S. S., and M. Wilk. 1965. An analysis of variance test for normality. Biometrika 52:591-601.

Watkins, G. H., A. R. Burriel, and J. E. T. Jones. 1991. A field investigation of subclinical mastitis in sheep in Southern England. Br. Vet. J. 147:413-420.

Wellnitz, O., A. Baumert, M. Saudenowa, and R. M. Bruckmaier. 2010. Immune response of bovine milk somatic cells to endotoxin in healthy quarters with normal and very low cell counts. J. Dairy Res. 77:452-459.

Winter, P., and I. G. Colditz. 2002. Immunological responses of the lactating ovine udder following experimental challenge with Staphylococcus epidermidis. Vet. Immunol. Immunopathol. 89:57-65. 